\title{
Pemanfaatan Kondisi Sosial Ekonomi Masyarakat Pesisir Dalam Membudidaya Bandeng di Desa Rupe Kecamatan Langgudu Kabupaten Bima.
}

\author{
Rizcky Juliawan \& Eva Nursa'ban \\ Dosen STKIP Harapan Bima \\ risky.juliawan@gmail.com
}

\begin{abstract}
Abstrak Desa Rupe termasuk wilayah yang berada di Kabupaten Bima selatan tepatnya di pesisir teluk Waworada.Desa Rupe memiliki sumberdaya alam yang cukup potensial dan strategis dalam pemanfaatannya. Dalam pengolahan sumber daya alam, masyarakat yang bertempat tinggal di dataran rendah dan tinggi lebih memilih untuk memanfaatkan lahan pertanian.Sedangkan masyarakat yang tinggal di daerah pesisir pantai lebih memilih untuk memanfaatkan hasil laut seperti mencari ikan dan sejenisnya. Pada tahun-tahun terakhir ini masyarakat yang profesi sebagai petani dan nelayan bukan saja hanya pergi ke sawah dan mencari ikan, akan tetapi sebagian petani dan nelayan juga berprofesi sebagai pembudidaya bandeng demi menambah penghasilan untuk memenuhi kebutuhan hidupnya. Keadaan sosial-ekonomi merupakan suatu kedudukan yang diatur secara sosial dan menetapkan seseorang dalam posisi tertentu dalam struktur masyarakat. Pemberian posisi ini disertai pula seperangkat hak dan kewajiban yang harus dipenuhi oleh si pembawa status, adapun tujuan penelitian ini adalah 1)untuk mengetahui keadaan sosial-ekonomi masyarakat pesisir dalam membudidaya bandeng di Desa Rupe Kecamatan Langgudu Kabupaten Bima; 2)untuk mengetahui kendala masyarakat pesisir dalam membudidaya bandeng di Desa Rupe Kecamatan Langgudu Kabupaten Bima. Penelitian ini menggunakan metode kualitatif, subjek atau informan dalam penelitian ini adalah masyarakat pembudidaya bandeng di desa Rupe dan pengambilan informan dalam penelitian ini menggunakan teknik snowball sampling. Metode pengumpulan data yang di gunakan dalam penelitian ini adalah observasi, wawancara, dokumentasi. Teknik analisis data yang digunakan dalam penelitian ini adalah redukasi data, penyajian data, dan verifikasi. Berdasarkan hasil penelitian, di ketahui bahwa budidaya bandeng dapat memberikan lapangan pekerjaan, membatu kebutuhan keluarga, pendapatan yang menjanjikan, dan peran pemerintah sangatlah penting untuk meningkatkan taraf hidup masyarakat pesisir (nelayan).
\end{abstract}

\section{Kata kunci: Sosialekonomi, masyarakat pesisir, budidaya bandeng.}

\section{PENDAHULUAN}

Perikanan menyediakan sumber penting bagi pemenuhan sumber makanan, pendapatan, pekerjaan dan rekreasi. Jutaan manusia bergantung kepada perikanan sebagai mata pencaharian, sehingga perlu keterlibatan semua stakeholder untuk mengelola perikanan guna menjamin kecukupan ikan untuk generasi mendatang. Seiring dengan meningkatnya jumlah populasi, konsumsi ikan dari tahun ke tahun semakin meningkat.Ditambah lagi tahun tahun terakhir ini, ekspor ikan Indonesia ke luar negeri juga berjalan lancar dengan grafik meningkat. Tidak diragukan lagi dunia usaha perikanan di negara kita menjanjikan masa depan yang cerah bagi para pengusaha.
Kementerian Kelautan dan Perikanan (KKP) Tahun 2009 telah menetapkan kabupaten Bima sebagai kawasan minapolitan perikanan budidaya. Minapolitan merupakan kata yang berasal dari dua kata, mina (ikan) dan politan (kota), yang berarti kota perikanan. Kawasan minapolitan merupakan suatu konsep pembangunan kelautan dan perikanan yang memiliki wilayah dengan pendekatan sistem dan manajemen kawasan dengan prinsip integrasi, efisiensi, kualitas dan akselerasi.Dan untuk menjadikan Kabupaten Bima sebagai kawasan minapolitan industrialisasi perikanan budidaya dari hulu sampai ke hilir, maka produksi, pengolahan dan pemasaran harus menggunakan prinsip manajemen tersebut. Kabupaten Bima sendiri memang memiliki 
potensi besar yaitu di sektor perikanan laut, dimana potensi ikan yang dapat di ekspor maupun untuk konsumsi sendiri sedangkan untuk sektor perikanan air payau seperti bandeng, udang, juga potensi lainnya seperti rumput laut, garam serta mutiara yang diharapkan berkembang menjadi kawasan industri perikanan dan hasil laut. Dengan ditetapkannya Kabupaten Bima sebagai kawasan minapoltan, diharapkan dapat mendorong akan semua bidang yang terkait untuk merealisasikan Kabupaten Bima menjadi wilayah industrialisasi perikanan dan kelautan. Dalam hal ini kerjasama antar Pemerintah Provinsi Nusa Tenggara Barat dan pihak perbankan dalam sektor perikanan dan kelautan akan semakin terfokus untuk mendukung akan ketetapan dari Kementerian Kelautan dan Perikanan (KKP).

Potensi perairan pantai di Kabupaten Bima mencapai $9.455 \mathrm{Km} 2$, terdapat potensi ikan yang beraneka ragam baik ikan potensi ekspor maupun lokal sebesar 48.233 ton/tahun. Produksi perikanan selalu berada pada tingkat peningkatan pada tiap tahunnya. Dengan produksi tertinggi di hasilkan oleh usaha budidaya bandeng tercatat hasil produksi tahun 2009 mencapai 3.676,80 ton/tahun, tahun 2010 tercatat 3358,20 ton/tahun, 2011 tercatat 6881,20 ton/tahun, tahun 2012 tercatat 6930,60 ton/tahun, 2013 tercatat 4423,20 ton/tahun dan di tahun 2014 tercatat 5973,50 ton/tahun.

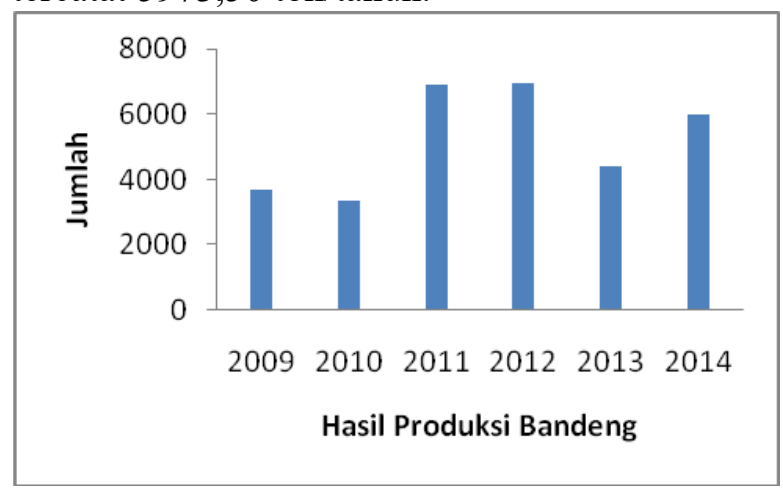

Gambar 1.1 : perkembangan produksi

bandeng pada tahun 2009-2015

Potensi Perikanan dan kelautan selain dari hasil tangkapan ikan laut, juga terdapat mutiara, rumput laut, dan budidaya tambak ikan bandeng dan udang, yang memang sudah terkenal hingga ke manca negara.
Penormalisasian lahan budidaya perikanan laut merupakan salah satu upaya yang dilakukan oleh Dinas Kelautan dan Perikanan serta Badan Perencanaan Pembangunan Daerah Kabupaten Bima untuk dapat membantu nelayan dan petani tambak untuk meningkatkan akan hasil perikanan laut dan tambak. Selain usaha Penormalisasian lahan budidaya, Dinas Kelautan dan Perikanan serta Badan Perencanaan Pembangunan Daerah Kabupaten Bima juga memberikan bantuan berupa penyediaan nener bandeng dan pakan, supaya nelayan tidak harus mencari di laut.

Desa Rupe termasuk wilayah yang berada di Kabupaten Bima selatan tepatnya di pesisir teluk Waworada.Desa ini memiliki sumberdaya alam yang cukup berpotensial dan strategis dalam pemanfaatannya.Dalam pengolahan sumber daya alam, masyarakat yang bertempat tinggal di dataran rendah dan tinggi lebih memilih untuk memanfaatkan lahan pertanian. Sedangkan masyarakat yang tinggal di daerah pesisir pantai lebih memilih untuk memanfaatkan lahan untuk kegiatan budi daya bandeng. Pada tahun-tahun terakhir ini masyarakat yang profesi sebagai petani dan nelayan bukan saja hanya pergi ke sawah dan mencari ikan, akan tetapi sebagian petani dan nelayan juga berprofesi sebagai pembudidaya bandeng demi menambah penghasilan untuk memenuhi kebutuhan hidupnya.

Berkaitan dengan hal yang dikemukakan di atas, penulis tertarik untuk meneliti tentang "Kajian sosial-ekonomi masyarakat pesisir dalam membudidaya bandeng di Desa Rupe Kecamatan Langgudu Kabupaten Bima".

\section{METODE PENELITIAN Rancangan Penelitian}

Dalam penelitian ini menggunakan metode penelitian kualitatif. Metode penelitian kualitatif sering disebut metode penelitian naturalistik karena penelitiannya dilakukan pada kondisi yang alamiah (natural setting); disebut sebagai metode kualitatif, karena data yang terkumpul dan analisinya lebih bersifat kualitatif.

Metode penelitian kualitatif adalah metode penelitian yang digunakan untuk 
meneliti pada kondisi obyek alamiah, (sebagai lawannya adalah eksperimen) dimana peneliti adalah instrumen kunci, tehnik pengumpulan data dilakukan secara trigulasi (gabungan) analisios dan bersifat induktif, dan hasil peneliti kualitatif lebih menekankan makna dari pada generalisasi (Sugiyono, 2013:15).

\section{Lokasi Penelitian}

Sebagaimana yang tertulis dalam judul penelitian bahwa lokasi yang dipilih adalah di Desa Rupe. Peneliti memilih Desa Rupe karena daerah asal peneliti sendiri dan memungkinkan akan mempermudah peneliti saat melakukan penelitian karena lokasi tersebut sudah dikuasai oleh peneliti.

\section{Jenis dan Sumber Data}

\section{Jenis Data}

Dalam melakukan penelitian harus bisa memahami jenis data sehingga bisa mencari metode apa yang sesuai dengan data yang diperoleh. Dengan demikian, dalam penelitian ini jenis data yang digunakan adalah data kualitatif yakni data yang dinyatakan dalam bentuk kata, kalimat dan gambar biasanya berhubungan dengan nilai. Misalnya baik-buruk dan tinggi-rendah.

Adapun jenis data yang dimaksud dalam penelitian ini adalah jenis kualitatif data yang berupa penjelasan tentang sosialekonomi masyarakat pembudidaya bandeng.

\section{Sumber Data}

Sumber data adalah subjek dari mana data diperoleh. Adapun sumber data dalam penelitian ini adalah sebagai berikut:

\section{Data Primer}

Sumber data primeradalah sumber asli, sumber tangan pertama peneliti. Dari sumber data primer ini akan dihasilkan data yang langsung diperoleh dari sumber data oleh penyidik untuk tujuan khusus. Sumber data primer adalah data yang langsung diperoleh dari observasi dan wawancara.

\section{Data Sekunder}

Data sekunder merupakan sumber data yang sudah dalam bentuk jadi, berupa dokumen, arsip-arsip, publikasi dan artikel mengenai masalah yang diteliti. Dalam penelitian ini data sekunder adalah dokumendokumen atau arsip-arsip mengenai keadaan sosial-ekonomi masyarakat pembudidaya bandeng di Desa Rupe KecamatanLanggudu Kabupaten Bima.

\section{Instrumen Penelitian}

Dalam buku metode penelitian dijelaskan bahwa "Instrumen penelitian adalah suatu alat yang digunakan untuk mengukur fenomena alam maupun sosial yang diamati” (Sugiyono, 2013:148). Berdasarkan pendapat diatas, maka yang dimaksud dengan instrumen adalah alat yang digunakan untuk memperoleh data tentang obyek yang diteliti. Dalam penelitian kualitatif yang menjadi instrumen atau alat penelitian adalah penelitiitu sendiri(Sugiyono, 2013:305). Oleh karena itu peneliti sebagai instrumen juga harus "divalidasi" seberapa jauh peneliti kualitatif siap melakukan penelitian yang selanjutnya terjun ke lapangan. Validasi terhadap peneliti sebagai instrumen meliputi validasi terhadap pemahaman metode penelitian kualitatif, penguasan wawasan terhadap bidang yang diteliti, kesiapan peneliti untuk memasuki obyek penelitian, baik secara akademik maupun logistiknya. Yang melakukan validasi adalah penelitian itu sendiri, melalui evaluasi diri seberapa jauh pemahaman terhadap metode kualitatif, penguasaan teori dan wawasan terhadap bidang yang diteliti, serta kesiapan dan bekal memasuki lapangan.

Penelitian kualitatif sebagai human instrumen, berfungsi menetapkan fokus penelitian, memilih informan sebagai sumber data, melakukan pengumpulan data, menilai kualitas data, analisis data, menafsirkan data dan membuat kesimpulan atas semuanya (Sugiyono, 2012:222). Yang menjadi instrumen dalam penelitian ini adalah peneliti sendiri dan dilengkapikamera, buku, alat tulis dan lembar kuisioner.

\section{Metode Penentuan Informan Pengertian Informan}

Menurut Moleong (2012:132), informan adalah orang yang dimanfaatkan untuk memberikan informasi tentang situasi dan kondisi latar penelitian. Jadi, ia harus mempunyai banyak pengalaman tentang latar penelitian. 


\section{Tehnik Penentuan Informan}

Menurut Sugiyono (2013:298), dalam penelitian kualitatif tidak menggunakan populasi, karena penelitian kualitatif berangakat dari kasus tertentu yang ada pada situasi sosial tertentu dan hasil kajiannya tidak akan diberlakukan kepopulasi, tetapi ditransferkan ketempat lain pada situasi sosial yang memiliki kesamaan dengan situasi sosial dengan kasus yang dipelajari. Sampel dalam penelitian kualitatif bukan dinamakan responden, tetapi sebagai narasumberatau partisipan, informan, teman dan guru penelitian. Sampel dalam penelitian kualitatif juga bukan disebut sampel statistik, tetapi sampel teoritis karena tujuan penelitian kualitatif adalah untuk menghasilkan teori. Dalam penelitian kualitatif tehnik sampling yang digunakan adalah purposive sampling dan snowball sampling(Sugiyono, 2012:219). Tehnik purposive sampling adalah tehnik pengambilan sampel sumber data dengan pertimbangan tertentu, misalnya orang tersebut yang dianggap paling tahu tentang apa yang kita harapkan, atau mungkin dia sebagai penguasa sehingga akan memudahkan peneliti menjelajahi obyek atau situasi sosial yang diteliti.Sedangkan snowball samplingadalah teknik pengambilan sampel sumber data yang pada awalnya jumlahnya sedikit, lama-lama menjadi besar. Hal ini dilakukan karena dari jumlah sumber data yang sedikit tersebut belum mampu memberikan data yang lengkap, maka akan dicari orang lain lagi yang dapat digunakan sebagai sumber data. Dengan demikian jumlah sampel sumber data akan semakin besar seperti bola salju yang menggelinding lama-lama akan menjadi besar (Sugiyono, 2012:218-219).

Pengambilan informan dalam penelitian ini dilakukan menggunakan teknik Snowball Sampling, karena peneliti akan mencari data tambahan terhadap jumlah informan yang apabila informan sebelumnya belum maksimal karena terlalu sedikit, sehingga dapat dilakukan penambahan jumlah informan penelitian agar data yang diambil sesuai dengan target dan harapan dalam pelaksana penelitian. Oleh karena itu yang menjadi informan dalam penelitian ini adalah masyarakat pembudidaya bandeng di Desa Rupe Kecamatan Langgudu Kabupaten Bima.

\section{Teknik Pengumpulan Data}

Teknik pengumpulan data merupakan langkah yang paling utama dalam penelitian, karena tujuan utama dari penelitian adalah mendapatkan data. Tanpa mengetahui teknik pengumpulan data, maka peneliti tidak akan mendapatkan data yang memenuhi standar data yang ditetapkan (Sugiyono, 2013:308). Adapun teknik pengumpulan data dalam penelitian ini adalah sebagai berikut:

\section{Metode Observasi}

Observasi merupakan suatu proses yang kompleks, suatu proses yang tersusun dari berbagai proses biologis dan psikologis. Dua diantara yang terpenting adalah prosesproses pengamatan dan ingatan (Sutrisnodalam Sugiyono, 2013:203).

\section{Metode Wawancara}

Wawancara adalah percakapan dengan maksud tertentu. Percakapan itu dilakukan oleh dua pihak, yaitu pewawancara yang mengajukan pertanyaan dan terwawncara yang memberikan jawaban atas pertanyaan itu. Maksud mengadakan wawancara antara lain: mengkontruksi orang lain, kejadian, perasaan motivasi dan lain-lain (Moleong, 2012:186).

Adapun wawancara yang digunakan dalam penelitian ini adalah wawancara semiterstruktur dan data yang ingin diperoleh dalam penelitian ini adalah mengenai pekerjaan, pendidikan dan pendapatan masyarakat pembudidaya bandeng.

\section{Metode Dokumentasi}

Dokumentasi merupakan catatan peristiwa yang sudah berlalu. Dokumen bisa berbentuk tulisan, gambar atau karya-karya monumental dari seseorang. Dokumen yang berbentuk tulisan misalnya catatan harian, sejarah kehidupan, biografi, peraturan dan kebijakan. Dokumen yang berbentuk gambar misalnya foto, gambar hidup, sketsa dan lainlain (Sugiyono, 2013:329).

Terkait dengan pendapat di atas, manfaat dokumentasi dalam penelitian ini adalah untuk memperoleh data kependudukan, mata pencaharian dan data 
keadaan sosial-ekonomi masyarakat, terutama yang berprofesi sebagai pembudidaya bandeng.

\section{Teknik Analisis Data}

Analisis data adalah proses mencari dan menyusun secara sistematis data yang diperoleh dari hasil wawancara, catatan lapangandan dokumentasi, dengan cara mengorganisasikan data kedalam kategori, menjabarkan kedalam unit-unit, melakukan sintesa, menyusun kedalam pola, memilih mana yang penting dan yang akan dipelajari dan membuat kesimpulan sehingga mudah dipahami oleh diri sendiri maupun orang lain (Sugiyono, 2013:335).

Menurut Miles dan Huberman (dalam Sugiyono, 2013:337), teknik analisis data yang digunakan dalam penelitian kualitatif adalah:

1) Reduksi data berarti merangkum, memilih hal-hal yang pokok, memfokuskan pada hal-hal yang penting, dicari tema dan polanya serta membuang yang tidak perlu.

2) Display data yaitu dilakukan dengan uraian singkat, bagan, hubungan antar kategori, flowchart dan sejenisnya.

3) Verifikasi adalah merupakan temuan baru yang sebelumnya belum pernah ada. Temuan dapat berupa deskripsi atau gambaran suatu objek yang sebelumnya masih remang-remang atau gelap sehingga setelah diteliti menjadi jelas, dapat berupa hubungan kausal atau interaktif, hipotesis atau teori.

\section{HASIL PENELITIAN}

\section{Gambaran Umum Lokasi Penelitian}

Gambaran umum Desa Rupe

Kecamatan Langgudu Kabupaten Bima adalah sebagai berikut.

a. Letak Geografis

Desa Rupe merupakan salah satu Desa yang berada di Kecamatan Langgudu Kabupaten Bima selatan tepatnya di pesisir teluk Waworada. Desa ini memiliki sumberdaya alam yang cukup berpotensial dan strategis dalam pemanfaatannya.Dalam pengolahan sumber daya alam, masyarakat yang bertempat tinggal di dataran rendah dan tinggi lebih memilih untuk memanfaatkan lahan pertanian.Sedangkan masyarakat yang tinggal di daerah pesisir pantai lebih memilih untuk memanfaatkan hasil laut seperti mencari ikan dan budi daya bandeng.

Dikarenakan memiliki wilayah pesisir, banyak masyarakat Desa Rupe yang bermata pencaharian sebagai nelayan ataupun berprofesi sebagai pembudidaya bandeng. Desa Rupe terdiri dari 4 dusun yaitu: 1) Dusun Oi vonu; 2) Dusun Mangge Maci; 3) Dusun Sori Nocu; 4) Dusun Luru Mbolo.

Lokasi penelitian dilakukan di Desa Rupe Kecamatan Langgudu Kabupaten Bima, dengan batas wilayah:

1. Sebelah utara berbatasan dengan Desa Kalodu

2. Sebelah selatan berbatasan dengan Teluk Wawoada

3. Sebelah barat berbatasan dengan Desa Karumbu

4. Sebelah timur berbatasan dengan Desa Sambane

b. Karakteristik Lokasi Penelitian

1. Luas Wilayah Desa RupeKecamatan Langgudu Kabupaten Bima

Luas wilayah Desa RupeKecamatan Langgudu Kabupaten Bima dapat dilihat pada tabel berikut ini:

TabelLuas wilayah Desa RupeKecamatan Langgudu Kabupaten Bima

\begin{tabular}{|r|l|r|}
\hline No & \multicolumn{1}{|c|}{ Nama } & \multicolumn{1}{c|}{$\begin{array}{c}\text { Luas } \\
\text { (Ha) }\end{array}$} \\
\hline 1 & Luas pemukiman & 120 \\
\hline 2 & Luas Persawahan & 350 \\
\hline 3 & Luas perkebunan & 174,13 \\
\hline 4 & Luas tambak & 25,7 \\
\hline 5 & Luas kuburan & 5,2 \\
\hline 6 & Luas Prasarana umum lainnya & 10,8 \\
\hline 7 & Jumlah & $685,83,3$ \\
\hline
\end{tabular}

Sumber :Profil Kantor Desa Rupe 2016

Desa Rupe memiliki berbagai jenis tanah yaitu tanah sawah yang terdiri dari sawah irigasi, tanah kering, tanah perkebunan, dan tanah fasilitas umum.

a. Sawah irigasi terdiri atas sawah tadah hujan $350 \mathrm{Ha}$

b. Tanah kering terdiri atas tegal/ladang 174,13 Ha, pemukiman $120 \mathrm{Ha}$, kuburan 5,2 ha dan fasilitas umum 10,8 ha, jadi 
jumlah luas tanah kering yang ada di Desa

Rupe yaitu 190,13 Ha.

2. Keadaan Penduduk Desa Rupe

Penduduk merupakansalah satu aspek dalam pembangunan yaitu sebagai modal pembangunan sekaligus sebagai penghambat pembangunan, kerena majunya suatu daerah sangat tergantung pada kualitas sumber daya manusia, oleh karena itu sebagai aspek yang sangat penting dan besar pengaruhnya terhadap kemajuan suatu daerah, maka perelu diupayakan pembangunan baik yang berkaitan dengan materi maupun spritual. Jumlah penduduk di Desa Rupe Kecamatan Langgudu Kabupaten Bima adalah bisa dilihat pada tebel dibwah ini:

Tabel 4.2 Jumlah Penduduk Desa Rupe Kecamatan Langgudu Kabupaten Bima

\begin{tabular}{|r|l|r|}
\hline No & \multicolumn{1}{|c|}{ Penduduk } & $\begin{array}{r}\text { Jumlah } \\
\text { (orang) }\end{array}$ \\
\hline 1 & Jumlah laki-laki & 1627 \\
\hline 2 & Jumlah perempuan & 1687 \\
\hline 3 & Jumlah total & 3314 \\
\hline 4 & Jumlah kepala keluarga & 851 \\
\hline
\end{tabular}

Sumber :Profil Kantor Desa Rupe 2016

Tabel 4.3 Tingkat Usia Penduduk Desa Rupe Kecamatan Langgudu Kabupaten Bima

\begin{tabular}{|c|l|r|r|}
\hline No & \multicolumn{1}{|c|}{ Usia } & \multicolumn{1}{|c|}{$\begin{array}{c}\text { Laki-laki } \\
\text { (orang) }\end{array}$} & $\begin{array}{c}\text { Perempuan } \\
\text { (orang) }\end{array}$ \\
\hline 1 & 0-15 Tahun & 384 & 516 \\
\hline 2 & 15-65 Tahun & 1023 & 991 \\
\hline 3 & $65 \quad$ Keatas & 220 & 180 \\
\hline 4 & Total & 1627 & 1687 \\
\hline
\end{tabular}

Sumber :Profil Kantor Desa Rupe 2016

3. Tingkat Pendidikan Desa Rupe

Selanjutnya distribusi penduduk di

Desa Rupe Kecamatan Langgudu Kabupaten Bima menurut agama dan kepercayaan yang dianut adalah penganut agama Islam 100\%.Sedangkan distribusi penduduk tingkat pendidikan dapat dillihat pada tabel berikut ini.

Tabel 4.4 Tingkat Pendidikan Penduduk Desa Rupe Kecamatan Langgudu Kabupaten Bima

\begin{tabular}{|c|l|r|}
\hline No & Tingkat pendidikan & \multicolumn{1}{|c|}{ Jumlah } \\
\hline 1 & Tidak tamat sekolah & 195 \\
\hline 2 & Tamat TK/sederajat & 68 \\
\hline 3 & Tamat SD/sederajat & 362 \\
\hline
\end{tabular}

Abdi Masyarakat

\begin{tabular}{|c|l|r|}
\hline 4 & Tamat SMP/sederajat & 889 \\
\hline 5 & Tamat SMA/sederajat & 1124 \\
\hline 6 & $\begin{array}{l}\text { Tamat D-1/D-2/D- } \\
\text { 3/sederajat }\end{array}$ & 89 \\
\hline 7 & Tamat S-I/sederajat & 582 \\
\hline 8 & Tamat S-2/sederajat & 5 \\
\hline
\end{tabular}

Sumber :ProfilKantor Desa Rupe 2016

4. Mata Pencaharian Penduduk Desa RupeKecamatan Langgudu Kabupaten Bima

Gambaran mata pencaharian atau tingkat ekonomi penduduk masyarakat Desa Rupe antara lain dapat dilihat pada tabel berikut ini:

Tabel 4.5 Jenis Mata Pencaharian PendudukDesa RupeKecamatan Langgudu Kabupaten Bima

\begin{tabular}{|c|l|r|}
\hline No & \multicolumn{1}{|c|}{ Jenis Pekerjaan } & $\begin{array}{r}\text { Laki-laki } \\
\text { (orang) }\end{array}$ \\
\hline 1 & Petani & 1270 \\
\hline 2 & Buruh/kuli & 59 \\
\hline 3 & Pegawai negeri sipil & 127 \\
\hline 4 & $\begin{array}{l}\text { Pengerajin industri rumah } \\
\text { tangga }\end{array}$ & 34 \\
\hline 5 & Pedagang keliling & 32 \\
\hline 6 & Peternak & 429 \\
\hline 7 & Nelayan & 246 \\
\hline 8 & Tenaga kesehatan & 23 \\
\hline 9 & TNI/POLRI & 15 \\
\hline 10 & PensiunPNS & 56 \\
\hline 11 & Pengusaha kecil dan \\
menengah & 14 \\
\hline 12 & Dosen swasta & 9 \\
\hline 13 & Tidak bekerja/tidak produktif & 1000 \\
\hline
\end{tabular}

Sumber :ProfilKantor Desa Rupe 2016

\section{Hasil Penelitian}

1. Keadaan Sosial-Ekonomi Masyarakat Pesisir Dalam Membudidaya Bandeng di Desa Rupe Kecamatan Langgudu Kabupaten Bima.

Berdasarkan aspek geografis, masyarakat pesisir merupakan masyarakat yang hidup, tumbuh dan berkembang di kawasan pesisir. Masyarakat ini bergantung hidup dengan mengelola sumber daya alam yang tersedia di lingkungannya yaitu kawasan perairan dan pulau-pulau kecil. Secara umum sumber ekomomi mereka ialah sumberdaya perikanan (tangkap dan budidaya) menjadi sumberdaya yang sangat 
penting dansumberdaya ini menjadi penggerak dinamika ekonomi lokal di desadesa pesisiran.

Dalam konteks ini, masyarakat nelayan merupakan pelaku utama yang ikut serta menentukan dinamika ekonomi local. Kondisi masyarakat nelayan kini, merupakan hasil dari kebijakan pembangunan di sektor perikanan yang disebut "modernisasi perikanan” sejak awal 1970-an, kebijakan yang bertumpu pada orientasi produktivitas ini telah melahirkan berbagai perubahan yang sangat penting di bidang sosial, ekonomi dan ekologi di masyarakat pesisir. Seiring dengan pertumbuhan produktivitas tangkap dan budidaya perairan, masalah-masalah sosial dan lingkunganpun bermunculan dan belum bias terselesaikan secara tuntas hingga kini.

Persoaalan pembangunan masyarakat pesisir dapat dikategorikan menjadi tiga, yaitu:

1. Masalah sosial yang mecakupi isu kemiskinan, kesenjangan sosial dan konflik sosial nelayan.

2. Masalah lingkungan yang mencakupi isu kerusakan ekosistem pesisir, pulau-pulau kecil dan kelangkaan sumberdaya perikanan.

3. Masalah modal pembangunan yang mencakupi isu pengelolaan potensi sumberdaya yang belum optimal dan masalah kepunahan desa nelyan atau surutnya peranan ekonomi desa nelayan beserta tradisi maritimnya.

Keadaan Sosial-Ekonomi Pesisir Dalam Membudidaya Bandeng di Desa Rupe Kecamatan Langgudu Kabupaten Bima dapat dijabarkan sebagai berikut:

a. Pekerjaan

Pekerjaan akan menentukan status sosial-ekonomikarena dari bekerja segala kebutuhan akan dapat terpenuhi. Pekerjaan seseorang akan mempengaruhi kemampuan ekonominya, untuk itu bekerja merupakan suatu keharusan bagi setiap individu sebab dalam bekerja mengandung dua segi, kepuasan jasmani dan terpenuhinya kebutuhan hidup.
1. Pendidikan

Pendidikan sangatlah penting peranannya dalam kehidupan bermasyarakat. Dengan memiliki pendidikan yang cukup maka seseorang akan mengetahui mana yang baik dan mana yang dapat menjadikan seseorang menjadi berguna baik untuk dirinya sendiri maupun untuk orang lain yang membutuhkannya. Dengan pendidikan dapat memperluas keilmuan, meningkatkan kemampuan dan potensi serta membuat seseorang lebih peka terhadap setiap gejalagejala sosial yang muncul

2. Pendapatan

Pendapatan akan mempengaruhi status sosial seseorang, terutama akan ditemui dalam masyarakat yang materialis dan tradisional yang menghargai status sosial ekonomi yang tinggi terhadap kekayaan.

Dari pendapat tersebut dapat diketahui bahwa status sosial ekonomi adalah kemampuan seseorang untuk mampu menempatkan diri dalam lingkungannya sehingga dapat menentukan sikap berdasarkan atas apa yang dimilikinya dan kemampuan mengenai keberhasilan menjalankan usaha dan berhasil.

3. Membuka lapangan kerja

Pada dasarnya tingkat kehidupan ekonomi seseorang atau masyarakat ditentukan oleh kesempatannya memperoleh sumber pendapatan, kesempatan kerja, dan kesempatan berusaha.Selengkapnya dapat dilihat dari hasil wawancara berikut ini.

Pengurangan jumlah pengangguran karena sebagian masyarakat bekerja menjadi tenaga kerja di budidaya bandeng. Sebagian besar pengangguran yang berkurang karena menjadi tenaga kerja di budidaya bandeng tenaga kerja laki-laki

\section{Kendala Masyarakat Pesisir Dalam Membudidaya Bandeng di Desa Rupe Kecamatan Langgudu Kabupaten Bima}

a. Faktor alam

Keadaan alam memang sangat berpengaruh terhadapat keberlangsungan budidaya bandeng, karena lokasi yang digunakan untuk membudidaya bandeng adalah di dekat pantai. 


\section{b. Faktor tenaga kerja}

Dalam melakukan budidaya sudah tentu memerlukan tenaga kerja yang akan melaksanakan proses budidaya baik mulai dari pembibitan, perawatan sampai pada proses panen.

c. Sumber Daya Manusia (SDM)

Salah satu faktor yang menentukan keberlangsungan pelaksanaan budidaya bandeng ini yaitu kualitas sumber daya manusia yang dimiliki dalam hal ini yang dimaksud adalah para pemilik.

Keterbelakangan dan kemiskinan bukanlah cerita baru bagi masyarakat pesisir.Berdasarkan ukurannya, kemiskinan dibagi menjadi dua kemiskinan absolute dan kemiskinan relative (Satria, 2002). Kemiskinan absolute adalah masyarakat yang secara alamiah benar-benar miskin berdasarkan ketentuan ukurannya.Sementara itu, kemiskinan relative merupakan kemiskinan dari suatu kelompok pendapatan bila dibandingkan dengan kelompok pendapatan lainnya.

Kemiskinan kultural terjadi karena faktor internal, nelayan miskin karena kurangnya modal dan keterbatasan teknologi dan manajemen bahkan karena sifat malas yang dimiliki oleh nelayan yang menyebabkan dia miskin.Berbeda dengan kemiskinan kultural yang timbul dari intern, kemiskinan struktural terjadi karena faktor eksternal misalnya adanya hambatan bagi mobilitas vertical nelayan, tidak adanya dukungan dari pemerintah atau hubungan praton-klien yang masih bersifat asimetris.

Aspek struktural menyebabkan lemahnya posisi nelayan atau pembudidaya ikan dalam pemasaran. Proses tawar menawar menyebabkan para nelayan sangat lemah dan tidak berdaya karena hasil produksi mereka yang masih minim. Selain itu, desakan kebutuhan yang memaksa nelayan untuk menerima tawaran harga dari pasar meskipun harga tersebut sangat merugikan nelayan. Sehingga kajian tentang pemberdayaan untuk mengatasi masalah para nelayan, kemiskinan dan keterbelakangan sangatlah penting.

\section{d. Kondisi Sarana dan Prasarana}

Keberadaan sarana dan prasarana merupakan merupakan salah satu modal untuk mendukung suatu proses.

Permasalahan mendasar dari kemiskinan yang terjadi di masyarakat tentunya para nelayan yang tidak berdaya adalah kurang terlibatnya para nelayan dalam pemberdayaan sosial ekonomi, yang diakibatkan kurangnya sarana dan prasana. Masyarakat kurang dilibatkan secara total dalam pelaksanaan program pembangunan yang menyangkut kepentingan diri mereka sendiri. Sedangkan pemberdayaan masyarakat seakan-akan menjadi new mainstream upaya bagi pengentasan kemiskinan. Keberhasilan suatu proses pemberdayaan dapat dilihat dari seberapa erat kerjasama antara masyarakat dan stakeholder dengan pihak pemerintah daerah. Menciptakan lapangan kerja dan mendekatkan masyarakat dengan sumber modal, teknologi dan pasar merupakan salah satu cara pendekatan dari proses pemberdayaan.

Setelah dikembangkannya program pemberdayaan di masyarakat pesisir, maka perlu adanya rancangan program-program yang dapat diimplementasikan sampai generasi mendatang, dapat mengatasi masalah kemiskinan masyarakat pesisir dan meningkatkan pendapatan para nelayan.Program pengentasan kemiskinan contohnya pengguna es dan rantai dingin.Nelayan menggunakan es untuk hasil tangkapan ikan mereka agar awet sejak ikan ditangkap sampai ikan tiba di pasar.

Program besar lain yang dilakukan oleh pemerintah untuk mengetaskan kemiskinan adalah pembangunan sarana perikanan khususnya pelabuhan perikanan dari yang paling kecil yang dimiliki nelayan sampai yang paling besar pelabuhan perikanan samudera. Selain program-program diatas, pengembangan koperasi perikanan, kelompok usaha bersama, dan pengembangan kemitraan usaha dapat dijadikan rujukan program untuk mengentaskan kemiskinan (Nikijuluw dalam Bangen, 2001). Selain program pengentasan kemiskinan, program pengelolaan. 
Wilayah pesisir juga sangatlah penting karena komunitas masyarakat pesisir bedomisili di wilayah pesisir dan menggantungkan hidupnya dengan sumberdaya yang terkandung di wilayah pesisir dan laut. Pada saat yang sama juga masyarakat harus bisa menjaga lingkungan dan ekosistem pesisir agar penggunaan sumberdaya pesisir tidak menimbulkan dampak negative (wawancara tanggal 05 Juni tahun 2016).

Langkah pertama program pengelolaan sumberdaya adalah mengidentifikasi isu dan masalah di wilayah pesisir, mengadakan program pendidikan penyuluhan bagi masyarakat, mengadakan kerjasama antara masyarakat dengan suatu lembaga.Program nyatanya adalah pengelolaan dan budidaya perikanan, pengembangan system agribisnis dalam upaya meningkatkan pendapatan para nelayan. Program lain adalah kebijakan pemerintah dalam pemanfaatan sumberdaya alam untuk mengembangkan pariwisata secara optimal namun seimbang antara manfaat lingkungan, manfaat sosial, dan manfaat ekonomi (wawancara tanggal 05 Juni 2016).

Namun perlu diperhatikan, pembangunan sarana pariwisata yang menggunakan sumberdaya dan keindahan lingkungan laut harus sesuai dengan ekowisata. Karena bias jadi hal tersebut dapat mengakibatkan tingginya biaya hidup setempat. Sementara itu, keunikan ekosistem di suatu lingkungan adalah nilai dasar dan modal utama yang dapat dijadikan landasan untuk mengembangkan pariwisata.

e. Kurangnya Peran Pemerintah

Masalah yang muncul dari beberapa kelembagaan adalah memperlakukan masyarakat pesisir dengan cara dan sudut pandang secara sama. Sejatinya, masyarakat tidak dapat diperlakukan dengan sama dalam aturan-aturan yang sifatnya mekanistik karena masyarakat bukanlah mesin. Kegagaln yang terjadi dalam proses pembangunan yang terjadi di masyarakat pesisir disebabkan karena kebanyakan dari proyek pembangunan yang dilakukan untuk masyarakat pesisir adalah proyek yang berorientasi hasil dengan mengabaikan proses pembangunan dan kultur masyarakat pesisir. Selain itu, banyak dari pihak luar yang kurang antusias dan kurang simpati dalam keikut sertaan membangun sumberdaya wilayah pesisir dan memberdayakan masyarakat setempat.

Munculnya masalah tersebut disebabkan oleh lemahnya system dan tata cara koordinasi antar stakeholder karena belum didukung dengan adanya system hukum yang mengatur kegiatan tersebut. Selain itu, lemahnya kualitas sumberdaya manusia yang mempengaruhi proses partisipatif menjadi tidak berjalan sebagaimana mestinya. Hal ini sering berdampak pada munculnya ketidaksepahaman dan konflik penggunaan ruang antar stakeholder dalam rangka menjaga keseimbangan keberlanjutan sumberdaya alam yang berada di sekitar wilayah pesisir dan laut.Oleh karena itu, terkait dengan permasalah-permasalahan tersebut di atas pengkajian kebijakan kelautan secara partisipatif dengan stakeholder dalam rangka pemberdayaan masyarakat pesisir sangat diperlukan.

Masyarakat pesisir memerlukan bentuk kegiatan nyata yang dapat membangun ekonomi mereka tanpa menghilangkan kultur dan karakteristik dari masyarakat pesisir tersebut. Berdasarkan Undang-Undang No. 22 tahun 1999 tentang desentralisasi dan otonomi daerah yang memberikan wewenang kepada daerah untuk mengurus sendiri segala urusan daerahnya.Begitu juga dengan wilayah pesisir, ketua masyarakat atau kepala suku dapat bekerjasama dengan penduduk untuk mengurus pesisir dan lautnya sesuai dengan adat mereka.Namun, disamping itu masyarakat pesisir harus bekerjasama juga dengan pemerintah atau BPL (Badan Penyuluhan Lapangan) untuk memberikan pendidikan dan pengetahuan kepada masyarakat supaya pengelolaan sumberdaya alam lingkungan laut dapat termanfaatan dengan baik dan lestari (Wawancara Tanggal 06 Juni Tahun 2016).

Pemerintah atau pihak luar harus memberikan wewenang kepada masyarakat dengan memberikan tanggung jawab penuh kepada masyarakat dalam pelaksanaan, pemantauan, penegakan aturan dan 
memberikan kesempatan terhadap masyarakat untuk mengemukakan strategi sesuai dengan keinginan mereka.Dewasa ini ada program yang belum banyak ditemukan di Indonesia yaitu Program Sumberdaya Wilayah Pesisir Berbasis Masyarakat (PSWP-BM).Program ini memiliki kapasitas dalam memperbaiki kualitas hidup mereka sendiri dan mampu mengelola sumberdaya mereka dengan baik. Partisipasi masyarakat terhadap kegiatan pengelolaan sumberdaya berbasis masyarakat akan berjalan secara berkelanjutan berdasarkan tingkat pengendalian stakeholder

Proses pengelolaan sumberdaya yang dilaksanakan dengan program dan modelmodel pendekatan terhadap masyarakat pesisir, dapat memberikankeleluasan terhadap masyarakat pesisir yang karakternya cenderung keras dan tegas dalam mengembangkan keahlian mereka secara optimal. Selain itu, baik kegiatan atau program yang dicanangkan oleh pemerintah harus bersifat fleksibel, agar dapat disesuaikan dengan kondisi dan kebutuhan masyarakat.

\section{PEMBAHASAN}

Masyarakat pesisir merupakan suatu komunitas yang hidup di wilayah pesisir dan menggantungkan hidupnya dengan sumberdaya pesisir.Masyarakat pesisir termasuk masyarakat yang masih terbelakang dan berada dalam posisi marginal.Selain itu, banyak dimensi kehidupan yang tidak diketahui oleh orang luar tentang karakteristik masyarakat pesisir. Masyarakat pesisir mempunyai cara berbeda dalam aspek pengetahuan, kepercayaan, peranan sosial, dan struktur sosialnya. Sementara itu, dibalik kemarginalnya, masyarakat pesisir tidak mempunyai banyak cara dalam mengatasi masalah yang hadir. Masalah kompleks yang dihadapi masyarakat pesisir adalah kemiskinan, keterbatasan pengetahuan untuk mengelola sumberdaya dan teknologi, serta peran aktif antara pihak luar dengan masyarakat pesisir sehingga dapat menghidupkan kualitas dan keterampilan masyarakat pesisir tanpa melunturkan karakter budayanya.
Masyarakat pesisir yang memiliki karakter tegas, keras, dan terbuka memerlukan berbagai strategi dan kegiatan yang bersifat fleksibel agar dapat berubah sesuai dengan kondisi dan kebutuhan mereka. Pemberdayaan masyarakat berbasis masyarakat merupakan salah satu cara untuk mengatasi kemiskinan dan ketidakberdayaan yang dialami oleh masyarakat pesisir khususnya para nelayan. Program-program yang dilakukan pemerintah untuk pemberdayaan masyarakat pesisir telah banyak menghasilakan manfaat dan membantu meningkatkan pendapatan masyarakat.Namun, tidak sedikit pula program-program yang tidak berhasil karena tidak sesuai dengan harapan masyarakat dan tidak ada keberlanjutan dari masyarakat.

Keadaan Sosial-Konomi Masyarakat Pesisir Dalam Membudidaya Bandeng di Desa Rupe Kecamatan Langgudu Kabupaten Bima dapat dijabarkan sebagai berikut:

1. Pekerjaan

Pekerjaan akan menentukan status sosial-ekonomi karena dari bekerja segala kebutuhan akan dapat terpenuhi. Pekerjaan seseorang akan mempengaruhi kemampuan ekonominya, untuk itu bekerja merupakan suatu keharusan bagi setiap individu sebab dalam bekerja mengandung dua segi, kepuasan jasmani dan terpenuhinya kebutuhan hidup.

2. Pendidikan

Pendidikan sangatlah penting peranannya dalam kehidupan bermasyarakat, dengan memiliki pendidikan yang cukup maka seseorang akan mengetahui mana yang baik dan mana yang dapat menjadikan seseorang menjadi berguna baik untuk dirinya sendiri maupun untuk orang lain yang membutuhkannya. Dengan pendidikan dapat memperluas keilmuan, meningkatkan kemampuan dan potensi serta membuat seseorang lebih peka terhadap setiap gejalagejala sosial yang muncul.

3. Pendapatan

Pendapatan akan mempengaruhi status sosial seseorang, terutama akan ditemui dalam masyarakat yang materialis dan 
tradisional yang menghargai status sosial ekonomi yang tinggi terhadap kekayaan.

\section{SIMPULAN}

Berdasarkan hasil penelitian maka dapat ditarik kesimpulan yaitu sebagai berikut:

1. Keadaan Sosial-Ekonomi Masyarakat Pesisir Dalam Membudidaya Bandeng di Desa Rupe Kecamatan Langgudu Kabpaten Bima meliputi pekerjaan, pendidikan, pendapata dan pembukaan lapangan pekerjaan. Artinya pendapatan masyarakat meningkat, hal ini sangat dipengaruhi oleh jenis pekerjaan mereka, karena sebelum berprofesi sebagai pembudidaya bandeng mereka tidak mampu memenuhi semua kebutuhan keluarganya, setelah mereka berprofesi sebagai pembudidaya bandeng segala kebutuhannya dapat terpenuhi.

2. Kendala Masyarakat Pesisir Dalam Membudidaya Bandeng di Desa Rupe Kecamatan Langgudu Kabupaten Bima meliputi faktor alam, faktor tenaga kerja, sumberdaya manusia (sdm) dan kondisi sarana dan prasarana.

\section{SARAN}

Adapun saran berdasarkan hasil dari penelitian, maka dapat dianjurkan saran tindak lanjut sebagai berikut:

1. Memberikan sumbangan pemikiran dalam pengembangan ilmu pengetahuan tentang keadaan sosial-ekonomi masyarakat pesisir dalam membudidaya bandeng.

2. Bagi instansi pemerintah, sebagai data informasi mengenai manfaat dari keberadaan kegiatan budidaya bandeng bagi kesejahteraan masyarakat.

3. Dapat menjadi bahan pertimbangan bagi pemerintah dan kalangan praktisi yang hendak memberikan sumbangan pemikirannya terhadap kesejahteraan masyarakat nelayan, terutama yang berkaitan langsung dengan masyarakat pembudidaya bandeng.

\section{DAFTAR PUSTAKA}

. 2006. Filosofi Pemberdayaan Masyarakat

Pesisir. Bandung: Humaniora 2013. Metode Penelitian Pendidikan. Bandung. Alfabeta, CV.
Bambang Cahyono. 2011. Budidaya Ikan Bandeng. Pustaka Mina Jakarta.

http://deradesrita.blogspot.co.id/2011/11/ikan -bandeng-chanos-chanos.html. Diakses; 15 Desember 2015. Mataram.

http://dokumen.tips/documents/pkm-k-usahapendederan-bandeng.html. Diakses; 15

Desember 2015. Mataram.

http://media.unpad.ac.id/thesis/230110/2009/ 2301100900612 1476.pdf. Diakses;

15 Desember 2015. Mataram.

https://syifaamalia22.wordpress.com/2012/04/ 15/definisi-budaya. Diakses; 29 April 2016. Mataram

Jhingan, M.L.1995. Ekonomi Pembangunan dan Perencanaan. Jakarta: Gramedia

Kusnadi. 2000. Neleyan: Strategi Adaptasi Dan Jaringan Sosial. Bandung: Humaniora Utama Press.

Moleong. 2012. Metode Penelitian Kualitatif. PT Remaja Rosdakarya Offset Bandung.

Purnomowati, I., Hidayati, D., dan Saparinto, C. 2007. Ragam Olahan Bandeng.

Kanisius.Yogyakarta.

Rindawan, R., \& Syahrir, S. (2019). Kompetensi Guru Pendidikan Jasmani Olahraga dan Kesehatan Dalam Pelaksanaan Evaluasi Pembelajaran SMAN 1 Praya Barat Daya Tahun 2018. JISIP: Jurnal Ilmu Sosial dan Pendidikan, 3(1).

Soekanto. 1984. Teori Sosiologi tentang Perubahan Sosial. Jakarta: Ghalia Indonesia.

Sugiyono, 2012. Metode Penelitian Kuantitatif, Kualitatif dan $R \& D$. Bandung. Alfabeta, CV.

Supardan. 2008. Pengantar Ilmu Sosial. Jakarta:Bumi Aksara.

Syahrizal. 2002. Dalam Skripsi Peran Pariwisata Dalam Meningkatkan Kesejahteraan Hidup Masyarakat. UIN Sunan Giri Djati Bandung

Waluya, bagja. 2009. Sosiologi: Menyelami Sosial di Masyarakat. PT. Pribumi Mekar 